\title{
DOES Cleome droserifolia HAVE ANTI-SCHISTOSOMIASIS MANSONI ACTIVITY?
}

\author{
Nahla S. EL-SHENAWY, Maha F.M. SOLIMAN \& Ismail M. ABDEL-NABI
}

\begin{abstract}
SUMMARY
The present study was undertaken to assess the effect of the crude extract of Cleome droserifolia (CD) leaves on experimentally infected mice with Schistosoma mansoni. Two groups of mice, showing a patent infection of S. mansoni, one of them was daily treated with an alcoholic extract of $\mathrm{CD}$ leaves $\left(0.31 \mathrm{~g} \mathrm{~kg}^{-1}\right.$ body weight, i.p.) for 21 days. The schistosomicidal activity of the $\mathrm{CD}$ extract was evaluated, three weeks post-treatment, on some parasitological and histopathological aspects including worm load, oogram pattern, faecal eggs releasing and granuloma formation. In addition, serum thyroid hormones levels (tri-iodothyronine; $\mathrm{T}_{3}$ and tetra-iodo-thyronin; $\mathrm{T}_{4}$ ), serum total protein contents and hepatic reduced glutathione (GSH) were evaluated. Treatment using $\mathrm{CD}$ extract resulted in a weak reduction in worm burden $(32.46 \%)$ and affected the viability of both mature and immature eggs as indicated by the increase in the percentage of dead eggs and the decrease in the percentage of live ones. In addition, a week posttreatment, eggs elimination was observed in the stool of the infected-treated group which was low compared to the infected group. There was a suppressive effect of the extract on granuloma formation that could be due to the antioxidant effect of the extract. These data are confirmed by increasing hepatic GSH, serum total proteins and thyroid hormone levels in the infected-treated group as compared to the infected group. Treatment significantly enhanced $\beta$ globulin fractions of the protein. Based on these assumptions, $\mathrm{CD}$ extract has beneficial effects on thyroid hormones status and anti-schistosomiasis activity. The beneficial effects of CD extract could be related to its direct effects on the parasite, and secondary to its effect on the antioxidant capacity of the host. The present study could emphasize the precise mechanism (s) of CD extract protection.
\end{abstract}

KEYWORDS: Cleome droserifolia; Schistosoma mansoni; Experimental studies; Biochemical aspects.

\section{INTRODUCTION}

Schistosomiasis is a widespread helminthic disease. Schistosomiasis tops all the endemic parasitic diseases world-wide particularly in $\mathrm{Egypt}^{8}$. There is yet no vaccine available and the current mainstay of control is chemotherapy with praziquantel. In view of concern about the development of tolerance and/or resistance to praziquantel, there is a need for research and development of novel drugs for the prevention and cure of schistosomiasis ${ }^{30}$.

Most pathology in schistosome-infected animals is attributed to the host's reaction to the eggs, which is maximal by the $8^{\text {th }}$ week of infection. The toxic egg material destroys the host tissue cells and the antigenic material stimulates the development of large inflammatory reactions (granuloma) around the egg material ${ }^{29}$. This granuloma is considered to serve as a protective barrier by sequestering the toxic and antigenic substances secreted continuously from Schistosoma eggs, thereby, preventing further diffusion of these harmful materials ${ }^{24}$. Schistosoma mansoni infection develops unique severe granulomatous inflammatory reactions in the liver that lead to certain dysfunction, which represents the start of various fatal consequences, associated with this disease ${ }^{2}$.
High rate of oxidative processes, formation of hepatic malondialdehydein due to the peroxidative damage to the liver microsomal membrane lipid and impairment of the antioxidant defense characterize schistosomiasis ${ }^{10,11}$. Among the antioxidant defense mechanisms is hepatic reduced glutathione (GSH) that removes reactive oxygen species once formed ${ }^{4}$.

The importance of several hormones (insulin, steroids and thyroid hormone) on worm development, egg production and the way schistosomes might exploit host signaling molecules to evade the hosts' immune system was emphasized ${ }^{21,26}$.

The role of plants extract in this regard has been recently investigated. Artemether, the methyl ether derivative of artemisinin, exhibited antischistosomal properties alone and in combination with praziquantel $^{30}$. Treatment of Schistosomiasis with Myrrh, an oleo-gum resin from the stem of Commiphora molmol plant, resulted in death of living Schistosoma ova in patient biopsy and proved to be very effective and safe in the treatment of schistosomiasis haematobium ${ }^{8,27}$. Plant extracts from Abrus precatorius (Leguminosae), Pterocarpus angolensis (Leguminosae) and Ozoroa insignis (Anacardiaceae) were 
lethal to adult schistosomes ${ }^{22}$. However, it has been reported that oral administration of alcoholic extract of Ambrosia maritima leaves has a negligible effect on $S$. mansoni in mice ${ }^{1}$.

Cleome droserifolia, family Capparaceae ${ }^{5}$, commonly grown in different areas of North Sinai, Egypt. It is used for folk medicine in Egypt; especially in Sinai for treatment of diabetes mellitus ${ }^{16}$ since it has hypoglycemic properties ${ }^{23}$. It is also used traditionally for the treatment of scabies, rheumatism, and inflammation ${ }^{15}$. In addition, it has been reported that it has antimalarial effect ${ }^{23}$. The methanol extract of $C$. droserifolia has two flavonoids active components ${ }^{12}$. Recently, C. droserifolia had proved to have antioxidant activity on diabetic rats ${ }^{9}$.

Therefore, the present study was undertaken to assess the effect of the crude extract of $C$. droserifolia leaves on granuloma formation and parasite load as well as on biochemical parameters of experimentally infected mice with $S$. mansoni.

\section{MATERIALS AND METHODS}

Preparation and dose of extracts: The raw material was collected from Arish, North Sinai, and Egypt and authenticated to C. droserifolia (Forssk.) by Dr. W. Kamel. The voucher specimen was deposited in Department of Botany, Faculty of Science, Suez Canal University. The leaves and small branches of the plant were thoroughly washed with distilled water to remove dirt and soil. They were shade dried. The materials were coarsely powdered and extracted by cold percolation using $95 \%$ ethanol till exhaustion ${ }^{7}$. These extracts were concentrated for further studies at reduced temperature and pressure in a rotary evaporator. The ethanol was evaporated to give crude ethanolic extract. Extracts after concentration were suspended in 1\% Tween-80 for intraperitoneal (i.p.) administration. It was daily administered to mice at dose of $0.31 \mathrm{~g} \mathrm{~kg}^{-1}$ body weight. This dose was determined according to preliminary studies that proved its effectiveness.

Animals: Thirty male Swiss albino mice weighing 20-22 g were obtained from experimental research center of Theodor Bilharz Institute, Cairo, Egypt. They housed in polypropylene cages in an air conditioned area at $25 \pm 2{ }^{\circ} \mathrm{C}$ with $12 \mathrm{~h} / 12 \mathrm{~h}$ light/dark cycle, and had free access to pelletal food with tap water ad libitum. After randomization into various groups, the mice were acclimatized for seven days before initiation of experiment.

Chemicals and instrument: Tween-80 synthesis grades: Stharlaau Chemie S. A.; glutathione: Aldrich chemical Co. LTD-Germany; Kit for total protein: Bio-Rad Laboratories, Hercules, CA, USA; enzymelinked immunosorbent assay kit: Mercodia AB, Uppsala, Sweden; electrolyte buffer (Tris-barbital-sodium barbital): Electra HR buffer Helena, Laboratories, U.K., Cat \# 5805; Ponceau's fixative dye solution: Helena Biosciences, Sunderland, Tyne and wear, SR 53XB; All the other chemical: E. Merck, Germany; spectrophotometer: UV-visible, Unicom, Helios Alpha-9423 UVA 1000K-England; homogenizer: a Potter-Elvejham; an electric centrifuge: Remi Udyog, New Delhi; densitometer scanning: Tumors markers centre, Faculty of Medicine, Suez Canal University.

Experimental design: The animals were randomly divided into three groups with ten mice in each group. Group I was given Tween-80 and used as normal control mice. Group II and III were infected transcutaneously by exposing them to 50 cercariae per mouse of $S$. mansoni (Egyptian strain) and served as infected control and infectedtreated groups, respectively. Animals of group II received Tween-80 and served as infected control. Daily treatment with CD extract for 21 days was started from the $49^{\text {th }}$ day post infection (p.i.).

Blood and liver sample collection: After 21 days of daily extracts treatment (70 days of cercarial exposure), blood samples were retroorbitally collected from the inner canthus of the eye under light ether anesthesia using capillary tubes (Micro Hematocrit Capillaries, Mucaps). Blood was collected in clean vials and serum was separated in an electric centrifuge at $3000 \mathrm{rpm}$ for $10 \mathrm{~min}$. In addition, liver was excised from each animal after sacrification by decapitation, and dissected out in ice-cold saline and then thoroughly rinsed. The tissue was cut into fragments and homogenized to a known volume of certain buffer.

Parasite load, faecal eggs releasing and granuloma formation: Seventy days after cercarial exposure, all animals were sacrificed. Adult worms were recovered from the portal and mesenteric veins by perfusion ${ }^{28}$. Oogram pattern was determined according to the method of KATZ et al. ${ }^{18}$. Feacal samples were collected three times per week starting from week 7 p.i. until week 10 p.i., from each mouse and were processed according to the Kato-Katz technique ${ }^{18}$.

Granulomas diameters were measured in haematoxylin and eosinstained liver sections by using an optical micrometer; 70 granulomas with central ovum were examined. Intensity of granuloma formation/ $\mathrm{mm}^{2}$ was analyzed.

\section{BIOCHEMICAL ESTIMATION}

Glutathione assay: Hepatic reduced glutathione (GSH) levels were determined $^{3}$. GSH in protein-free supernatant was determined at 412 $\mathrm{nm}$ and expressed in $\mathrm{mg} \mathrm{g}^{-1}$ tissue. The GSH concentrations of the samples were derived from the standard curve prepared using known amounts of GSH.

Protein contents measurement: Serum total protein contents were determined using the Bio-Rad protein assay Reagent according to the instruction of the kit.

Thyroid hormones determination: Serum tri-iodothyronine; $\mathrm{T}_{3}$ and tetra-iodothyronin; $\mathrm{T}_{4}$ levels were determined by an enzyme-linked immunosorbent assay $\mathrm{kit}^{6,19}$.

Blood electrophoretic pattern: Technique of cellulose acetate zone electrophoresis was used for analyzing albumin and globulin in serum ${ }^{25}$. Electrophoresis of sample in Tris-barbital-sodium barbital, $\mathrm{pH} 8.8$, was performed for 25 minutes and the current was adjusted to 250 volts. Separated protein bands were visualized in characteristic positions after being stained (Ponceau's fixative dye solution) for five minutes and rinsed in 95\% glacial acetic acid: ethanol (3:7; V/V). Densitometer scanning converted bands to characteristic peaks of albumin, $\alpha_{1^{-}}, \alpha_{2}-$, $\beta$ - and $\gamma$-globulins.

Statistical analysis: All data were conducted with the software 
packages Microsoft SPSS version 11.0, for statistical evaluation. Results are expressed as mean \pm S.E. The results were analysed for statistical significance by one way ANOVA followed by Tukey-Kramer multiple comparisons test.

\section{RESULTS}

Worms recovery and intestinal oogram pattern: Results of worm recovery and intestinal oogram pattern from the infected groups were shown in Table $1 \& 2$. Extract treatment seemed to affect the worm burden moderately with a reduction rate of $32.46 \%$ as compared to the infected group; the reduction rate was specifically high in the number of total female worms $(\mathrm{p}<0.05)$. Consequently, the sexual bias (male per female worms) was changed in infected-treated mice. CD extract affected the viability of both mature and immature eggs as indicated by the increase in the percentage of dead eggs and the decrease in the percentage of live ones (Table 2).

Faecal eggs releasing: The kinetics of faecal egg output (Fig. 1) was characterized by an increasing in the number of eggs with the duration of infection. Starting from week 8 p.i.; one-week post treatment, eggs elimination was observed in the infected-treated group. This elimination of eggs reached to a stable phase with egg-laying significantly lower than the infected control group in week 9 and 10 p.i.

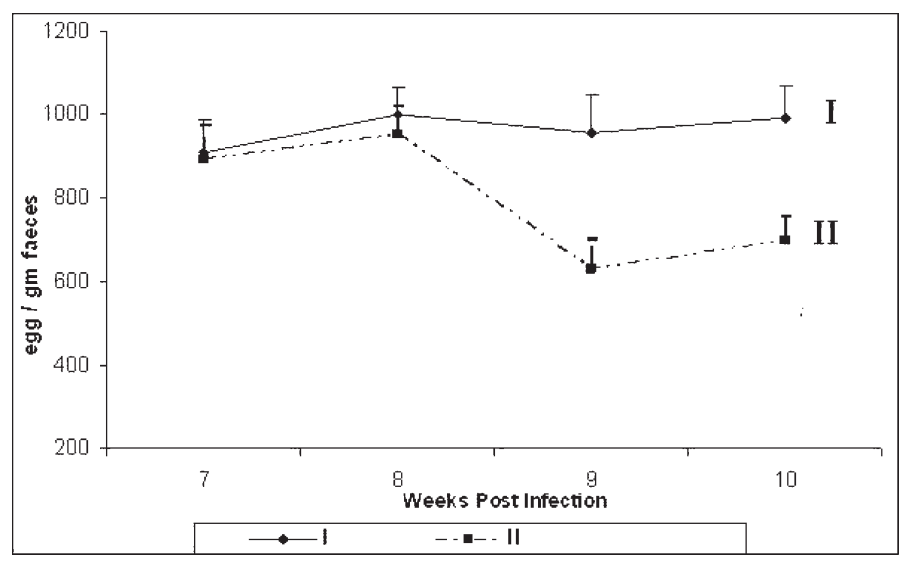

Fig. 1 - Kinetics of faecal eggs releasing from $S$. mansoni-infected mice following CD extract treatment at week 7, 8, 9 and 10 p.i. I: Infected; II: Infected-treated group. ${ }^{\text {a }}$ Significantly different from positive infected mice $(\mathrm{p}<0.05)$.

Characteristic of the granuloma: The various stages of granuloma evolution were present in both infected control and infected-treated groups with clear predominance of exudative type in treated mice (Table 3 ). Crude extract significantly reduced the size of hepatic granulomas compared to infected mice $(\mathrm{p}<0.001)$ (Table 3$)$. On the contrary, the

Table 1

Effect of 21 days administration of CD extract on male and female worm's recovery of S. mansoni-infected mice at the $10^{\text {th }}$ week p.i.

\begin{tabular}{llllllll}
\hline Groups & $\begin{array}{l}\text { Male worms } \\
\text { hepatic }\end{array}$ & $\begin{array}{l}\text { Female worms } \\
\text { hepatic }\end{array}$ & $\begin{array}{l}\text { Total worms } \\
\text { hepatic }\end{array}$ & $\begin{array}{l}\text { Male worms } \\
\text { mesentery }\end{array}$ & $\begin{array}{l}\text { Female worms } \\
\text { mesentery }\end{array}$ & $\begin{array}{l}\text { Total worms } \\
\text { mesentery }\end{array}$ & $\begin{array}{l}\text { Mean total } \\
\text { worms }\end{array}$ \\
\hline $\begin{array}{l}\text { Infected } \\
\begin{array}{l}\text { control } \\
\text { Infected- } \\
\text { treated }\end{array}\end{array}$ & $7.1 \pm 0.6$ & $3.4 \pm 0.2$ & $10.5 \pm 0.8$ & $7.5 \pm 0.5$ & $5.1 \pm 0.3$ & $12.6 \pm 0.8$ & $23.1 \pm 1$ \\
\hline
\end{tabular}

Values are represented as mean $\pm \mathrm{SE}(\mathrm{n}=8) .{ }^{\text {a }}$ Significantly different from positive infected mice $(\mathrm{p}<0.05)$. Treatment with CD extract started from the $49^{\text {th }}$ day p.i.

Table 2

Effect of 21 days administration of CD extract on intestinal oogram pattern of $S$. mansoni-infected mice at the $10^{\text {th }}$ week p.i.

\begin{tabular}{lllllll}
\hline Group & $\begin{array}{l}\text { Dead } \\
\text { immature }\end{array}$ & $\begin{array}{l}\text { Dead } \\
\text { mature }\end{array}$ & $\begin{array}{l}\text { Total } \\
\text { dead }\end{array}$ & $\begin{array}{l}\text { Early } \\
\text { immature }\end{array}$ & $\begin{array}{l}\text { Late } \\
\text { mature }\end{array}$ & $\begin{array}{l}\text { Mature } \\
\text { Total } \\
\text { live }\end{array}$ \\
\hline Infected control & $9.4 \pm 0.6$ & $2.9 \pm 0.3$ & $12.3 \pm 0.9$ & $19.6 \pm 2.0$ & $36.1 \pm 3.9$ & $32.0 \pm 1.9$ \\
Infected-treated & $24.3 \pm 2.5^{\mathrm{a}}$ & $15.3 \pm 2.4^{\mathrm{a}}$ & $39.5^{\mathrm{a}} \pm 4.9$ & $8.5^{\mathrm{a}} \pm 1.4$ & $24.5^{\mathrm{a}} \pm 0.6$ & $27.5 \pm 3.4$ \\
\hline
\end{tabular}

Values are represented as mean $\pm \mathrm{SE}(\mathrm{n}=8)$. ${ }^{\text {a }}$ Significantly different from positive infected mice $(\mathrm{p}<0.05)$. Treatment with $\mathrm{CD}$ extract started from the $49^{\text {th }}$ day p.i.

Table 3

Effect of 21 days administration of CD extract on granuloma formation in S. mansoni-infected mice at the $10^{\text {th }}$ week p.i.

\begin{tabular}{lllll}
\hline Groups & $\begin{array}{l}\text { Mean granuloma diameter } \\
(\mu \mathrm{m})\end{array}$ & $\begin{array}{l}\text { Mean granuloma } \\
\text { intensity/mm }\end{array}$ & $\begin{array}{l}\text { \% Exudative } \\
\text { granuloma }\end{array}$ & $\begin{array}{l}\text { Involutional } \\
\text { Granuloma }\end{array}$ \\
\hline Infected control & $242.3 \pm 18.4$ & $0.76 \pm 0.1$ & 59.3 & 40.7 \\
Infected-treated & $157.3^{\mathrm{a}} \pm 15.3$ & $0.5 \pm 0.1$ & 70.9 & $29.1^{\mathrm{a}}$ \\
\hline
\end{tabular}

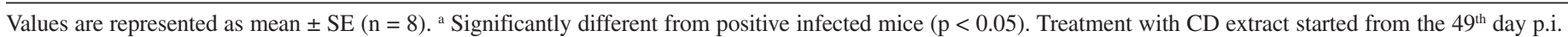


number of granuloma/mm² was not affected by treatment (Table 3). Figure 2 (A \& B) shows a remarkable decrease in the fibrotic area of granuloma after treatment.

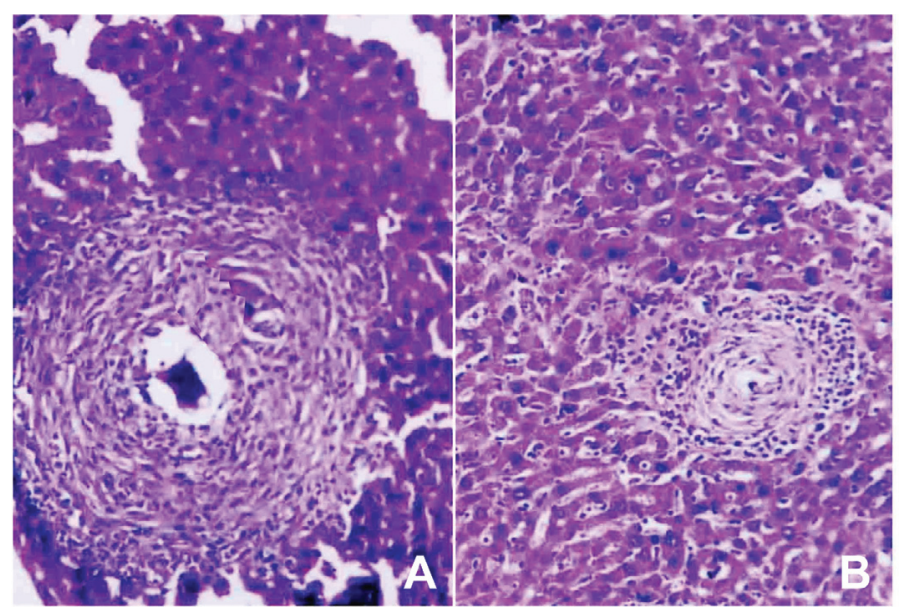

Fig. 2 - (A): Section in liver of S. mansoni-infected mice shows the presence of granuloma. (B) Liver of infected-treated mice shows the reduction of granuloma area (X 200).

Hepatic GSH: Significant decline in hepatic GSH of infected mice was observed as compared with those of normal control mice $(\mathrm{p}<$ 0.001). By the end of third week, the hepatic GSH levels were significantly elevated in the infected-treated group as compared with infected mice (Table 4).

Table 4

Effect of 21 days administration of CD extract on thyroid hormones, GSH, serum total protein and its fractions in S. mansoni- infected mice at the $10^{\text {th }}$ week p.i.

\begin{tabular}{lccc}
\hline Parameters & $\begin{array}{c}\text { Normal } \\
\text { control }\end{array}$ & $\begin{array}{c}\text { Infected } \\
\text { control }\end{array}$ & $\begin{array}{c}\text { Infected- } \\
\text { treated }\end{array}$ \\
\hline Liver & $5.4 \pm 0.1$ & $3.7 \pm 0.1^{\mathrm{a}}$ & $4.8 \pm 0.3^{\mathrm{b}}$ \\
$\mathrm{GSH}\left(\mathrm{mg} \mathrm{g}^{-1}\right)$ & $264.8 \pm 10.4$ & $186.2 \pm 12.9^{\mathrm{a}}$ & $231.2 \pm 9.4^{\mathrm{b}}$ \\
Serum & $44.3 \pm 2.7$ & $31.4 \pm 1.3^{\mathrm{a}}$ & $39.2 \pm 0.9^{\mathrm{b}}$ \\
$\mathrm{T}_{3}\left(\mathrm{ng} \mathrm{dl}^{-1}\right)$ & $7.8 \pm 0.4$ & $4.5 \pm 0.3^{\mathrm{a}}$ & $6.0 \pm 0.4^{\mathrm{b}}$ \\
$\mathrm{T}_{4}\left(\mathrm{nmol} \mathrm{dl}^{-1} \mathrm{l}\right)$ & 63.7 & 57.2 & 60.0 \\
${\text { Total protein }\left(\mathrm{g} \mathrm{dl}^{-1}\right)}^{\text {Albumin }(\%)}$ & 17.7 & $9.4^{\mathrm{a}}$ & 13.4 \\
$\alpha$ Globulin $(\%)$ & 29.6 & - & $8.4^{\mathrm{b}}$ \\
$\beta$ Globulin $(\%)$ & 19.0 & $11.4^{\mathrm{a}}$ & 16.8 \\
$\gamma$ Globulin $(\%)$ & 1.5 & 0.9 & 1.2 \\
A/G ratio & &
\end{tabular}

Values are represented as mean $\pm \mathrm{SE}(\mathrm{n}=8)$. Infected control was compared with normal control and treated group was compared with infected control. Values are statistically significant at ${ }^{\mathrm{a}} \mathrm{p}<0.001$ and ${ }^{\mathrm{b}} \mathrm{p}<0.001$. Treatment with $\mathrm{CD}$ extract started from the $49^{\text {th }}$ day p.i.

Hormonal level: The levels of $\mathrm{T}_{3}$ and $\mathrm{T}_{4}$ were decreased in infected mice as compared with normal control group. Significant increase in both hormones levels $(\mathrm{p}<0.01)$ were observed following treatment with CD extract (Table 4) as compared with infected control group.
Total protein and electrophoresis: As seen in Table 4, serum total proteins content of infected-mice was increased significantly with crude extract treatment. Electrophoresis was used for analyzing serum proteins, albumin level did not show any significant difference when the infected group was compared with normal control group or infectedtreated group. The globulin fractions (alpha and gamma; $\alpha \& \gamma$ ) were significantly decreased while, $\beta$-globulin was absent in the infected mice as compared with normal control. Treatment of the infected mice with the crude extract significantly enhanced $\beta$ globulin fractions of the protein. A/G ratio was lower in the case of infected-mice than that of normal control and infected-treated groups (Table 4).

\section{DISCUSSION}

Application of $C$. droserifolia powder in paste form is common ethnobotanical practice for the treatment of scabies, rheumatism, and inflammation ${ }^{15}$. Its extract had proved to have antioxidant activity on diabetic rats ${ }^{9}$. In the present study, this ethnobotanical practice was examined to investigate its possible anti-schistosomiasis effect on mice.

Daily administration of CD extract for 21 days has a pronounced antischistosomal activity where it diminished granuloma sizes extensively and decreased number of involutive granulomas as compared with the infected control mice. These findings might suggest a possible antifibrotic role of $\mathrm{CD}$ extract. It has been mentioned that patients with chronic schistosomiasis often fail to resolve hepatic fibrosis after eradication of the worms by antihelmintic treatment ${ }^{20}$. Moreover, it has been revealed that there is an important role of antioxidant processes in mediating liver injury in schistosomiasis due to an increased production of reactive oxygen intermediates ${ }^{10}$. Hence, the suppressive effect of $\mathrm{CD}$ extract on granuloma formation is probably due, in part, to the fact that this extract has antioxidants effect ${ }^{9}$.

Apparently, in the present study CD extract affected the oogram pattern with high percentage of dead eggs. In treated mice, high percentage of immature and mature dead eggs and low live ones compared with the infected mice could be related to a possible lethal effect of CD extract on eggs. In addition, the significant decrease in faecal eggs releasing may be attributed to the remarkable reduction in the worm load especially the female worms. All these findings may suggest a possible antischistosomiasis activity of the present extract.

It has been reported that schistosomiasis caused an impairment of liver GSH content of mice ${ }^{10}$. Decreasing the antioxidant capacity of the liver, leading to the generation of lipid peroxides that may play a central role in the pathology associated with schistosomiasis ${ }^{20}$. In the present study, hepatic GSH decreased significantly by $31.5 \%$ in infected mice as compared with the normal control group, which indicates that schistosomiasis causes more liberation of free radicals. In contrast, CD extract raised the hepatic GSH by $29.7 \%$ when compared with the infected-mice.

The follicular cells of the thyroid gland are responsible for the synthesis and release of thyroid hormones that regulate the basal metabolic rate and appropriate indicators of thyroid function ${ }^{13}$. Results obtained herein showed that both $\mathrm{T}_{3}$ and $\mathrm{T}_{4}$ levels were suppressed by schistosomiasis infection as previously reported ${ }^{14}$. Several systemic non-thyroid diseases induce subnormal $\mathrm{T}_{3}$ levels indicating impaired 
microsomal capacity to convert $\mathrm{T}_{4}$ to $\mathrm{T}_{3}$ and the mechanism behind that is the development of oxidative states ${ }^{17}$. Therefore, it is reasonable to conclude that infection-induced liver damage could be the mechanism behind the observed decrease in $\mathrm{T}_{3}$ of infected mice. Disturbance in thyroid hormones function should result in general failure of energy metabolism of the host that may affect in way or another energy metabolism of the parasite. This could be a hypothesis that linking $\mathrm{T}_{3}$ and $\mathrm{T}_{4}$ depletion accompanying schistosomiasis to impaired reproductive capacity of the worm. However, CD extract restored the serum $\mathrm{T}_{3}$ back to its normal levels which seems to be secondary to its effect as an antioxidant.

Decrease of serum total protein (hypoproteinemia) of infected mice than normal control group might be ascribed to the exaggerated liver damage caused by infection. In fact decreased amino acids uptake or hepatic protein synthesis was reported to be due to liver disease ${ }^{13}$. The present study showed a decrease in alpha and beta globulin needed for the transport of $\mathrm{T}_{3}$ and $\mathrm{T}_{4}$ as previously described ${ }^{31}$. Therefore, serum depletion of $\mathrm{T}_{3}$ and $\mathrm{T}_{4}$ might be due to lacking of thyroid binding proteins needed for their transport. In addition, the congenital absence of one or more of the plasma protein fractions indicates a defect in blood immunity ${ }^{31}$. Therefore, the suppression of thyroid hormones in the present study was consistent with previous study ${ }^{14}$. However, the effect of $\mathrm{CD}$ extract in increasing thyroid hormone levels may reflect its capability to stimulate the hepatic $\mathrm{T}_{4} / \mathrm{T}_{3}$ conversion and to improve the synthetic capacity of the thyroid cells ${ }^{13}$.

Based on these assumptions, CD extract has beneficial effects on thyroid hormones status and anti-schistosomiasis activity. The beneficial effects of $\mathrm{CD}$ extract could be related to its direct effects on the parasite, and secondary to its effect on the antioxidant capacity of the host. The present study could emphasize the precise mechanism(s) of $\mathrm{CD}$ extract protection.

\section{RESUMO}

\section{Cleome droserifolia tem atividade anti-esquistossomose mansônica?}

O presente estudo foi realizado para verificar o efeito do extrato cru de folhas de Cleome droserifolia (CD) em camundongos experimentalmente infectados com Schistosoma mansoni. Em dois grupos de camundongos mostrando infecção patente por $S$. mansoni, um deles foi tratado diariamente com extrato alcoólico de folhas de CD (0.31 $\mathrm{g} \mathrm{kg}^{-1}$ por peso corporal, i.p.) por 21 dias. A atividade esquistossomicida do extrato de CD foi avaliada, três semanas após o tratamento, em alguns aspectos parasitológicos e histopatológicos incluindo carga parasitária, padrão de oograma, eliminação fecal de ovos e formação de granuloma. Além disto, níveis séricos de hormônio tireoideano (tri-iodotironina: $\mathrm{T}_{3}$ e tetra-iodotironina: $\mathrm{T}_{4}$ ), conteúdo sérico total de proteínas e glutatione hepático reduzido $(\mathrm{GSH})$ foram avaliados. Tratamento usando extrato de $\mathrm{CD}$ resultou em fraca redução da carga de vermes $(32,46 \%)$ e afetou a viabilidade de ovos maduros ou não, como indicado pelo aumento na porcentagem de ovos mortos e o descrécimo na porcentagem de ovos viáveis. Além disso, uma semana após o tratamento, a eliminação de ovos foi observada nas fezes do grupo infectado-tratado que foi baixa comparada ao grupo infectado. Houve efeito supressivo do extrato sobre a formação de granuloma que poderia ser devido ao efeito antioxidante do extrato.
Estes dados são confirmados pelo aumento do GSH hepático, soro total de proteínas e níveis dos hormônios tireoideanos no grupo infecto-tratado quando comparado com o grupo infectado. O tratamento aumentou significativamente as frações beta-globulina da proteína. Baseado nestas afirmativas o extrato de CD tem efeitos benéficos sobre o nível dos hormônios tireoideanos e da atividade anti-esquistossomica. Os efeitos benéficos do extrato de $\mathrm{CD}$ poderiam estar relacionados com seu efeito direto sobre o parasita, e secundariamente por seus efeitos na capacidade anti-oxidante do hospedeiro. O presente trabalho poderia enfatizar o(s) mecanismo(s) preciso(s) desta proteção do extrato de CD.

\section{REFERENCES}

1. ABADOME, F.; GEERTS, S. \& KUMAR, V. - Evaluation of the activity of Ambrosia maritima L. against Schistosoma mansoni infection in mice. J. Ethnopharm., 44: 195-198, 1994

2. AL-SHARKAWI, L.M. \& BOLKINI, Y. - The protection effect of Thiola on hepatic derangement induced by paracetamol administration to the albino rats of different thyroidal dysfunction. J. Egypt. Ger. Soc. Zool., 29(A): 327-334, 1999.

3. BEUTLER, E.; DURON, O. \& KELLY, B.M. - Improved method for the determination of blood glutathione. J. Lab. clin. Med., 61: 882-888, 1963.

4. BONNEFONT-ROUSSELOT, D.; BASTARD, J.P.; JAUDON, M.C. \& DELATTRE, J. Consequences of the diabetic status on the oxidant/antioxidant balance. Diabet. Metab., 26: 163-176, 2000.

5. BOULOS, L. - Flora of Egypt; Azollaceae-Oxalidaceae. Cairo, Al-Hadara, 1999. v. 1, p. 170.

6. CHOPRA, I.J.; SOLOMON, D.H. \& HO, R.S. - A radioimmunoassay of thyroxine. J. clin. Endocrinol. Metab., 33: 865-868, 1971.

7. EGYPTIAN PHARMACOPOEIA. Cairo, Organization for Government Printing Office, 1984. v. 2, p. 1158.

8. EL BAZ, M.A.; MORSY, T.A.; EL BANDARY, M.M. \& MOTAWEA, S.M. - Clinical and parasitological studies on the efficacy of Mirazid in treatment of schistosomiasis haematobium in Tatoon, Etsa Center, El Fayoum Governorate. J. Egypt. Soc. Parasit., 33: 761-776, 2003.

9. EL-SHENAWY, N.S. \& ABDEL-NABI, I.M. - Comparative analysis of the protective effect of melatonin and Cleome droserifolia extract on antioxidant status of diabetic rats. Egypt. J. Hospit. Med., 14: 11-25, 2004.

10. EL-SHENAWY, N.S. \& SOLIMAN, M.F.M. - Evaluation of the protective effect of two antioxidative agents in mice experimentally induced with Schistosoma mansoni: biochemical and parasitological aspects. J. Egypt. Ger. Soc. Zool., 40(A): 201-216, 2003.

11. EL-SOKKARY, G.H.; OMAR, H.M.; HASSANEIN, A.F.; CUZZOCREA, S. \& REITER, R.J. - Melatonin reduces oxidative damage and increases survival of mice infected with Schistosoma mansoni. Free rad. Biol. Med., 32: 319-332, 2002.

12. FUSHIYA, S.; KISHI, Y;; HATTORI, K. et al. - Flavonoids from Cleome droserifolia suppress NO production in activated macrophages in vitro. Planta med., 65: 404$407,1999$.

13. GUYTON, A.C. \& HALL, J.E. - Textbook of medical Physiology. 10. ed. Philadelphia, W.B. Saunders, 2000. p. 810-818.

14. HASSAN, A.H.; ABD EL MONEIM, M.A.; ABD EL AAL, A.A. et al. - Circulating growth hormone, insulin-like growth factor I, cortisol and free thyroxine in children with schistosomiasis with and without hepatic fibrosis. J. trop. Pediat., 37: 25-30, 1991. 
15. HUSSEIN, N.S.; AHMED, A.A. \& DARWISH, F.M.K. - Sesquiterpenes from Cleome droserifolia. Pharmazie, 49: 76-77, 1994.

16. ISMAEL, L.D. - Pharmacognostical study of certain Cleome species growing in Egypt. Al-Azhar, 1992. (Thesis of master degree - Faculty of Pharmacology, Al-Azhar University).

17. ITOH, S.; YAMAGISHI, F. \& MATSUYAMA, Y. - Relationship between liver microsomal function and serum thyroid hormones in rats treated with carbon tetrachloride. Res. Commun. chem. Path. Pharmacol., 65: 111-114, 1989.

18. KATZ, N.; CHAVES, A. \& PELLEGRINO, J. - A simple device for quantitative stool thick-smear technique in Schistosomiasis mansoni. Rev. Inst. Med. trop. S. Paulo, 14: $397-400,1972$

19. KLOETZEL, K. - Egg and pigment production in Schistosoma mansoni infections of the white mouse. Amer. J. trop. Med. Hyg., 16: 293-299, 1967.

20. LIEWENDAHL, K. - Assessment of thyroid status by laboratory methods: developments and perspectives. Scand. J. clin. Lab. Invest., 201(suppl.): 83-92, 1990.

21. MAHMOUD, M.R.; EL-ABHAR, H.S. \& SALEH, S. - The effect of Nigella sativa oil against the liver damage induced by Schistosoma mansoni infection in mice. J. Ethnopharm., 79: 1-11, 2002.

22. MENDONÇA, R.L.; ESCRIVA, H.; BOUTON, D.; LAUDET, V. \& PIERCE, R.J. Hormones and nuclear receptors in schistosome development. Parasit. today, 16: 233-240, 2000

23. NDAMBA, J.; NYAZEMA, N.; MAKAZA, N.; ANDERSON, C. \& KAONDERA, K.C. - Traditional herbal remedies used for the treatment of urinary schistosomiasis in Zimbabwe. J. Ethnopharm., 42: 125-132, 1994.

24. NICOLA, W.G.; IBRAHIM, K.M.; MIKHAIL, T.H.; GIRGIS, R.B. \& KHADR, M.E. Role of the hypoglycemic plant extract Cleome droserifolia in improving glucose and lipid metabolism and its relation to insulin resistance in fatty liver. Boll. chim. farm., 135: 507-517, 1996.
25. PELLEGRINO, J.; OLIVEIRA, C.A.; FARIA, J. \& CUNHA, A.S. - New approach to the screening of drugs in experimental Schistosomiasis mansoni in mice. Amer. J. trop. Med. Hyg., 11: 201-215, 1962.

26. PHILLIPS, S.M. \& LAMMIE, P.J. - Immunopathology of granuloma formation and fibrosis in schistosomiasis. Parasit. today, 2: 296-302, 1986.

27. RAND, T.L. \& MURRAY, R.K. - Plasma protein, immunoglobulins, and blood coagulation. In: MARRAY, R.K.; GRANNER, D.K.; MAYES, P.A. \& RODWELL, V.W., ed. Harper's biochemistry. New Jersey, 1999. p. 737-739.

28. SALZET, M.; CAPRON, A. \& STEFANO, G.B. - Molecular crosstalk in host-parasite relationships: schistosome and leech-host interactions. Parasit. today, 16: 536-540, 2000

29. SHEIR, Z.; NASR, A.A.; MASSOUD, A. et al. - A safe, effective, herbal antischistosomal therapy derived from myrrh. Amer. J. trop. Med. Hyg., 65: 700-704, 2001.

30. SMITHERS, S.R. \& TERRY, R.J. - The infection of laboratory hosts with cercariae of Schistosoma mansoni and the recovery of adult worm. Parasitology, 55: 695-700, 1965

31. SOLIMAN, M.F.M. \& EL-SHENAWY, N.S. - Evaluation of the protective effect of two antioxidative agents in mice experimentally infected with Schistosoma mansoni: haematological and histopathological aspects. Pak. J. biol. Sci., 6: 887-897, 2003.

32. UTZINGER, J.; XIAO, S.; N'GORAN, E.K.; BERGQUIST, R. \& TANNER, M. - The potential of artemether for the control of schistosomiasis. Int. J. Parasit., 31: 15491562,2001

33. WILLIAM, F.G. - Circulating blood fluid. In: WILLIAM, F.G. Review of medical physiology. 20. ed. Stanford, McGraw- Hill, 2001. p 522-524.

Received: 3 October 2005

Accepted: 20 April 2006 